\title{
Vascular Endothelial Growth Factor B
}

National Cancer Institute

\section{Source}

National Cancer Institute. Vascular Endothelial Growth Factor B. NCI Thesaurus. Code C105598.

Vascular endothelial growth factor B (207 aa, $22 \mathrm{kDa}$ ) is encoded by the human VEGFB gene. This protein plays a role in both the formation of blood vessels and endothelial cell physiology. 